\title{
Teaching Listening Skills Online with Authentic Materials: A Study Involving Tertiary Level Students
}

\author{
Subhrajyoti Chanda \\ Department of English, Jorhat College (Amalgamated), Jorhat The English \\ and Foreign Languages University, Shillong Campus, Shillong
}

\section{ABSTRACT}

The COVID-19 pandemic situation that caused havoc in all fields including education - quite interestingly - also created scope for experiments in the field of language learning in a virtual setup that had to be adopted out of necessity. The students as well as the teachers, so long used to a traditional face - to - face classroom, had to rely essentially upon online engagements. The researcher, as a language teacher, tried to experiment with the feasibility of giving listening skills practice with authentic materials available on the web to tertiary level students and study the outcome of such enterprise. The paper aims to give an account of the online teaching of listening skills, designing and execution of listening tasks/ listening practice tasks and also present the effect of the exercise. It is expected that the findings from the enterprise would benefit both the learners and the teaching fraternity.

KEY WORDS: LISTENING SKILLS, TASKS, ONLINE, MICRO SKILLS, STRATEGIES.

\section{INTRODUCTION}

Listening can be called the fundamental language skill that humans come to term with; babies start with listening and then move on to speaking; reading and writing happen at a later stage. The development of listening skills is crucial not only for the learning of the L1(first language) but also for the subsequent learning of an L2 (Second language) or an FL (foreign language). So, there is a justification in emphasising the role of focussed teaching of listening skills. The researcher, who is also a teacher in a college in Upper Assam, has learnt from his experience of teaching for more than a decade that students had little exposure to English audio content a few years back - the English they heard in the classroom was most often their only exposure to the language. But, nowadays, the ubiquitous presence of smart phones among students made it plausible for the researcher to assume - at least hypothetically - that learners can listen to quality English audio texts if they wanted. But there

Biosc Biotech Res Comm P-ISSN: 0974-6455 E-ISSN: 2321-4007

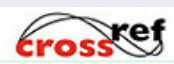

Identifiers and Pagination

Year: 2021 Vol: 14 No (8) Special Issue

Pages: $130-138$

This is an open access article under Creative

Commons License Attribn 4.0 Intl (CC-BY).

DOI: $h t t p: / / d x$.doi.org/10.21786/bbrc/14.8.30

are certain other questions which need to be addressed:

a. whether the students are interested in listening to English in the web;

b. and whether they have information about good authentic sources of English in the web.

With most of the language classes being conducted in the traditional face to face mode, it was not really possible for the researcher to experiment and learn much about the effects of online listening. The COVID-19 pandemic situation which ravaged India and the world, quite paradoxically, created the scope for experimenting with ways of teaching listening skills in the online mode as that, almost invariably, became the sole way of teaching and learning. It needs to be added here that the 21st Century skills demand, inter alia, the knowledge of information technology (IT) skills and communication skills; so, a research endeavour to study the impact of online listening instruction and practice can also be appreciated as an endeavour to upskill the participants with requisite 21 st Century skills.

2. Research Problem: Although the scope of exposure to English in the virtual mode is greater than in the faceto-face mode, there are doubts as to whether learners do expose themselves to good online content and also enjoy doing it. The current research aims to study the effect of guided online exposure and practice for the development of listening skills with respect to English language and

Article Information

Received: $10^{\text {th }}$ Apr 2021

ccepted after revision: $18^{\text {th }}$ June 2021 
also to study how far the participants could appreciate the endeavour of giving online English listening skills practice and instructions using authentic materials.

\section{Research Questions:}

The following are the set of research questions (RQs):

a. Is there a significant difference in participants' performance in pre-test and post-test scores so far as their factual comprehension skill in listening task is concerned?

b. Is there a significant difference in participants' performance in pre-test and post-test scores so far as their inferential comprehension skill in listening task is concerned?

c. Is there a significant difference in participants' performance in pre-test and post-test scores so far as their response evaluation skill in listening task is concerned?

d. Is there a significant difference in participants' performance in pre-test and post-test scores so far as their paraphrase recognition skill in listening task is concerned?

e. Is there a significant difference in participants' performance in pre-test and post-test scores so far as their listening skills as a whole is concerned?

4. Review Of Literature: The following sections present a review of literature on the subject.

4.1. Categories of listening tasks: Ur (1996) gives four categories of listening tasks:

a. tasks with no overt responses - where the "learners do not have to do anything in response to the listening; however, facial expression and body language often show if they are following or not";

b. tasks with short responses - which include activities such as obeying instruction, tick off items, true/false, detecting mistakes, cloze, guessing definitions, and skimming/scanning;

c. tasks with longer responses - which include answering questions in complete sentences, note taking, paraphrasing and translating, summarizing, and long gap filling;

d. tasks with extended responses - which include problem solving and interpretation; such activities have been described as “"combined skills' activities" (pp.113-114).

4.2. General research findings about listening strategies: Certain common facts about the use of strategies in listening tasks have been found by researchers - "such as listening to chunks of language rather than focusing on individual words, and avoiding direct translation", and also the use of metacognitive strategies for the purpose of monitoring of comprehension and also for "the successful orchestration of strategies" (Macaro, Graham, \& Vanderplank, 2007, p. 174).
4.3. Prior knowledge in the listening task: Having gone through a number of research findings on the use of prior knowledge, Macaro, Graham \&t Vanderplank (2007) list certain criteria necessary for the successful use of prior knowledge in listening tasks:

a. there must be congruence between the textual information and the prior knowledge of the listeners about it;

b. the lexical knowledge of the listener needs to "exceed a 'threshold' level"; and

c. the learners should know how to "make effective use of prior knowledge" such as being flexible with the use of prior knowledge or using it in combination (p.179).

4.4. What strategies research on listening skills have revealed: Research has almost conclusively proved that successful listeners make use of different strategies in different combinations unlike less successful listeners and that there are proofs that metacognitive strategies play a major role in the combination of strategies (Macaro, Graham, \&t Vanderplank, 2007, p. 184).

\subsection{Using authentic materials for development of} language skill: Real life listening tasks are motivating than artificially designed tasks for learners (Ur, 1996, p. 108). So, such tasks prepared with authentic materials can make the learners much involved in the tasks. Further, Ozverir, Osam and Herrington (2017), reporting on their research done on learning environment based on design principles of authentic activities implemented at pre-university level EFL classes in North Cyprus, note that they derived eleven design principles which have the potential to provide the right condition for the acquisition of English as a foreign language; the suggested quality traits of authentic activities are mentioned as follows:

a. these should have "real world relevance";

b. these should be "complex and ill-defined, requiring students to define the tasks and sub-tasks needed to complete the activity over a sustained period of time";

c. these should give scope to learners to use different perspectives and different types of resources;

d. these should create scope for collaboration;

e. these should create scope for reflections;

f. these should "lead beyond domain and skill specific outcomes";

g. these should be "seamlessly integrated with assessment"

h. these should result in products which are "valuable in their own right rather than as preparation for something else";

i. these should be "open-ended allowing competing solutions and diversity of outcome";

j. these should be "conducive to both learning and communication"; 
k. and these should "provide motivational factors".

The research conducted and reported by Ozverir et al. (2017) based on the eleven features revealed some interesting findings, it promoted:

a. the use of target language in conveying messages in written and spoken form in the EFL context; and b. the notion that authentic activities have the potential to bridge the gap "between language acquired in foreign language learning setting and the real world". The use of authentic activities they believe, can also help in situations where the target language is not spoken outside the institution by providing opportunities for the learners to make purposive and contextual use of the target language which can help in the internalization of target language structures. Further, they point out that language teaching is inextricably linked with higher order thinking skills and problem-solving skills and therefore authentic language activities can also help in the development of life skills.

4.6. Task based online language teaching: Lai, Zhao and Wang (2011) in their study of task-based language teaching in online foreign language classroom point out that a successful training programme includes certain micro level features:

a. students are to be guided to develop specific metacognitive strategies such as linguistic features of text-based chatting;

b. they are to be instructed as to how to "negotiate meaning" in online chatting;

c. they are also to be taught as to how to build rapport and maintain group dynamics in the online situation;

d. they are also to be instructed so as how to maintain optimum motivation and active engagement in the absence of instructors and peers.

4.7. Integrating online activities with the course and assessment structure: Hampels and Pleines (2013) reporting findings on a "two-year study exploring the design and implementation cycle of online activities as an integral part of a distance language course" write that "uptake of online activities increases the more firmly they are integrated with the course and assessment structure, with greater participation in those activities that are related to assessment".

4.8. Positive effects of synchronous and asynchronous tools and performance-based assessments: Sato, Chen and Jourdain (2017), reporting on their study on a fully online course for elementary Japanese courses at Stony Brook University, concluded that with regard to less commonly taught languages (LCTLs), a blend of synchronous and asynchronous tools proves most effective for students. They found that electronic tools could be effectively used for the purpose of assessment. As regards design of the course, they noted that "simultaneous, performancebased assessment approach can bring positive washback to students" foreign language learning experience and progression in distance education.

4.9. Mobile phones in language learning: Yu-Lin Jeng, Ting-Ting Wu, Yueh-Min Huang, Qing Tan, \& Stephen J. H. Yang (2010) note that the advancement in mobile technology has brought the "the impact of mobile learning on traditional pedagogical learning strategies". Yu-Lin Jeng et al. (2010) find that mobile technology does not complicate learning, rather help in the creation of an "augmented knowledge context environment pertaining to learners' daily life". Thus, advancement in mobile technology creates the scope for flexibility in learning on the part of the students and also creates scope for teachers to improvise traditional teaching. Mobile phones are ubiquitous, the many apps in the phone can surely aid in the process of language learning. Online teaching necessarily depends on apps. Rosell-Aguilar (2017) points out that there are certain device native apps or installed apps, not designed for language learning as such, but which can be of immense use in language learning using mobile phones. Rosell-Aguilar mentions such device native tools which can help in language learning: language settings; web browsers; multi lingual text input; speech to text tools; communication tools such as email, messaging, telephone, video conferencing which create opportunities for both synchronous and asynchronous communication; the photo/video camera which aid in content creations and also the satellite navigators.

4.10. Text Chat during video /audio conferencing in language learning: Research on text chats used in online sessions have shown conflicting results. Kozar's (2016) study about text chat during video/audio conferencing revealed contradictory findings - on one side, the study found instances of "negative, interfering effect of student - teacher interaction" and on the other side, chats were also useful for the language production of students. Kozar suggests more research on the effect of text chats during online language classroom.

\section{METHODOLOGY}

The following sections gives a detailed layout of the methodology for the current research.

5.1. The research project reported here was conceptualized as a study with twenty (20) students for a period of seven days in three broad phases in September 2020:

a. pre-test (first listening test) given at the beginning of the project;

b. online sessions on language learning strategies and micro skills of listening followed by rigorous practice sessions;

c. post-test (second listening test) given at the end of the project.

The students were exposed to rigorous listening practice tasks designed with authentic materials which were You Tube video texts (short BBC documentaries and popular English songs of 3 to 6 minutes). As stated, prior to giving 
practice, two sessions were held on language learning strategies and on micro skills of listening respectively. The participants were given a pre-test at the beginning of the exercise and post-test after exposing them to practice with authentic listening content; the scores were compared to know the difference in their performance. For a smooth engagement between the researcher and the students a WhatsApp group was created with those twenty students.

\begin{tabular}{|c|c|c|c|}
\hline $\begin{array}{l}\text { Sl. } \\
\text { no }\end{array}$ & $\begin{array}{c}\text { Pre-test } \\
\text { (Valley of flowers) }\end{array}$ & $\begin{array}{c}\text { Post-test } \\
\text { (Indian Elephants) }\end{array}$ & Type \\
\hline 1. & $\begin{array}{l}\text { The subject of the documentary is } \\
\text { a.plants of the Valley of Flowers } \\
\text { b.life in the Valley of Flowers } \\
\text { c. grandeur of the Valley of Flowers } \\
\text { d. animals of the Valley of Flowers }\end{array}$ & $\begin{array}{l}\text { The major threat to Indian } \\
\text { elephants came from } \\
\text { a. hunting for tusks } \\
\text { b.habitat destruction } \\
\text { c.human-animal conflict } \\
\text { d.hunger and climate change }\end{array}$ & $\begin{array}{c}\text { Factual } \\
\text { Comprehension }\end{array}$ \\
\hline 2. & $\begin{array}{c}\text { Gorals are } \\
\text { a. Himalayan goats } \\
\text { b. Himalayan small deer } \\
\text { c. Himalayan antelopes } \\
\text { d. Himalayan goat antelopes }\end{array}$ & $\begin{array}{l}\text { The annual demand for } \\
\text { slippers during the 1870s were } \\
\text { a.one billion } \\
\text { b.two billion } \\
\text { c.two million } \\
\text { d.one million }\end{array}$ & Factual Comprehension \\
\hline 3 & $\begin{array}{l}\text { The number of plant species } \\
\text { found in the Valley of Flowers is } \\
\text { a. more than } 500 \\
\text { b. more than } 600 \\
\text { c. more than } 6000 \\
\text { d. more than } 5000\end{array}$ & $\begin{array}{l}\text { One of the most } \\
\text { timeless scenes in India is } \\
\text { a. people bathing in the rivers ghats } \\
\text { b.elephants being used in processions } \\
\text { c.elephants being given river baths } \\
\text { d. elephants being traded in fares }\end{array}$ & $\begin{array}{c}\text { Factual } \\
\text { Comprehension }\end{array}$ \\
\hline 4. & $\begin{array}{l}\text { Nandadevi is } \\
\text { a. India's highest peak } \\
\text { b. India's steepest peak } \\
\text { c. India's second highest peak } \\
\text { d. India's most revered peak }\end{array}$ & $\begin{array}{l}\text { According to the documentary, } \\
\text { lives of captive elephants are } \\
\text { a.harder than those in the wild } \\
\text { b.easier than those in the wild } \\
\text { c.harsher than those in the wild } \\
\text { d. duller than those in the wild }\end{array}$ & $\begin{array}{c}\text { Factual } \\
\text { Comprehension }\end{array}$ \\
\hline 5. & $\begin{array}{l}\text { The soil type of the } \\
\text { Valley of Flowers is } \\
\text { a. glacial } \\
\text { b. icy } \\
\text { c. stony } \\
\text { d. sandy }\end{array}$ & $\begin{array}{l}\text { The sufferings of Indian } \\
\text { Elephants are really caused by } \\
\text { a. the British in India } \\
\text { b.rapid industrialization } \\
\text { c.circus performance } \\
\text { d.the trade in wild animals }\end{array}$ & $\begin{array}{c}\text { Factual } \\
\text { Comprehension }\end{array}$ \\
\hline 6. & $\begin{array}{l}\text { The colour of the } \\
\text { Himalayan Balsam is } \\
\text { a. red } \\
\text { b. blue } \\
\text { c. pink } \\
\text { d. yellow }\end{array}$ & $\begin{array}{l}\text { The sleepers in the 19th } \\
\text { Century were made of } \\
\text { a.iron } \\
\text { b.steel } \\
\text { c.concrete } \\
\text { d.wood }\end{array}$ & $\begin{array}{c}\text { Inferential } \\
\text { Comprehension }\end{array}$ \\
\hline 7. & $\begin{array}{l}\text { The statement - "In this remote } \\
\text { valley virtually everything has } \\
\text { to be home-grown" implies that } \\
\text { a. life is hard for locals } \\
\text { b. life is natural for locals } \\
\text { c. life is normal for locals } \\
\text { d. life is simple for locals }\end{array}$ & $\begin{array}{l}\text { Industrialization lead to } \\
\text { a. India's loss of traditional skills } \\
\text { b. India's loss of forest resource } \\
\text { c.India's loss of agricultural land } \\
\text { d.India's loss of self-dependence }\end{array}$ & $\begin{array}{c}\text { Inferential } \\
\text { Comprehension }\end{array}$ \\
\hline 8. & $\begin{array}{l}\text { The concluding statement - "It feels like } \\
\text { a high-altitude garden of Eden" } \\
\text { suggests that the Valley of Flowers is } \\
\text { a. an extremely beautiful and blessed place }\end{array}$ & $\begin{array}{l}\text { That elephants were used to } \\
\text { 'plunder' their own habitat } \\
\text { for timber shows that } \\
\text { a. humans are very exploitative }\end{array}$ & $\begin{array}{l}\text { Response } \\
\text { evaluation }\end{array}$ \\
\hline
\end{tabular}




\begin{tabular}{|c|c|c|c|}
\hline & $\begin{array}{l}\text { b. a beautiful place but not reachable } \\
\text { c. a place protected by goddess Nandadevi } \\
\text { d. a place for pilgrimage for Indians }\end{array}$ & $\begin{array}{l}\text { b. humans are very powerful } \\
\text { c. humans are very parasitic } \\
\text { d.humans are very dependent }\end{array}$ & \\
\hline 9. & $\begin{array}{l}\text { When the narrator says - } \\
\text { "Dominating the scene is } \\
\text { Nandadevi...", what does she mean - } \\
\text { a. Nandadevi takes care of the Valley of Flowers } \\
\text { b. Nandadevi towers over the Valley of Flowers } \\
\text { c. Nandadevi shelters the flowers and animals } \\
\text { d. Nandadevi controls the Valley of Flowers }\end{array}$ & $\begin{array}{l}\text { The expression "hurtling } \\
\text { towards industrial age" means } \\
\text { a. hastening fast towards industrialization } \\
\text { b. hurting oneself through industrialization } \\
\text { c.steadily moving towards industrialization } \\
\text { d. slowly moving towards industrialization }\end{array}$ & $\begin{array}{c}\text { Response } \\
\text { Evaluation }\end{array}$ \\
\hline 10 & $\begin{array}{l}\text { "Who could not believe that } \\
\text { this is a blessed place" means } \\
\text { a. Some would believe that } \\
\text { Valley of Flowers is a blessed place } \\
\text { b. Many would believe that Valley } \\
\text { of Flowers is a blessed place } \\
\text { c. No one would believe that } \\
\text { Valley of Flowers is a blessed place } \\
\text { Every one would believe that Valley of } \\
\text { Flowers is a blessed place }\end{array}$ & $\begin{array}{l}\text { The statement - "today...even working } \\
\text { elephants are being made redundant" means } \\
\text { a. working elephants are out of work } \\
\text { b.working elephants are becoming weak } \\
\text { c.working elephants are without food } \\
\text { d.working elephants are over employed }\end{array}$ & $\begin{array}{l}\text { Paraphrase } \\
\text { recognition }\end{array}$ \\
\hline
\end{tabular}

1. English Listening Skills Practice

Task 1 - MCQs based short BBC Documentary on You Tube http://youtube.com/watch?v=FCuS8H61-sE

Task 2 -MCQs based on the song "Take me home

country roads" by John Denver available on You Tube http://youtube.com/watch? v=oTeUdJky9rY

Task 3 - MCQs based on the song "Una Paloma Blanco"

by George Baker available on You Tube

http://youtube.com/watch? v=gQK9k42ongU

Task 4 - MCQs based on short BBC documentary:

http://youtube.com/watch?v=IFACrIx5SZ0

Task 5- MCQs based on the song "The Hills are alive..."

from the film The Sound of Music

http://youtube.com/watch? v=5fH2F0n1V5g

Task 6 - MCQs based on an interview with Bertrand Russel

http://youtube.com/watch? v=ihaB8AFOhZo

The questions designed for the study were multiple choice questions (MCQs). The rigorous practice sessions with authentic materials were aimed at raising the metacognitive awareness of the participants. The researcher tried to be as culturally relevant/suitable as possible so far as the choice of materials is concerned. The questions were also aligned with the objective of the compulsory 'Communicative English' paper of BA First Semester of Dibrugarh University so that the exercise was beneficial from the point of view of the university curriculum.

5.2 The following table would provide a comparison of the authentic texts used for the pre and the post-tests: (The pre-test is based on a short BBC Studios documentary titled "The Valley of Flowers" which was accessed from https://www.youtube.com/watch?v=FY8L08Dus64) (The post-test is based on a short BBC Studios documentary titled "Indian Elephants" which was accessed from https://www.youtube.com/watch?v=EtE6ruPPQk)

Prior to using the pre-test and post-test questions, these are piloted among another group of twenty students and the reliability score was found to be adequate. The validity is checked with teachers in the department where the researcher is working as an assistant professor.

5.3. The texts used in the practice tasks are given as follows:

5.4. Statistical tools used: For analysis of the data, the researcher used discreet statistics - paired sample t-test to compare the scores of the participants in the case study.

\section{Analyses And Interpretation:} 6.1. Quantitative analyses: 
RQ 1. Is there a significant difference in participants' performance in pre-test and post-test scores so far as their factual comprehension in listening task is concerned?.
The comparison of the mean scores in factual comprehension in listening tasks by the participants in the pre -test and post-test in Table $1(\mathrm{M}=3.30, \mathrm{SD}=.865$; $\mathrm{M}=3.75, \mathrm{SD}=.716$ ) shows a small increase.

Table 1. Paired Samples Statistics (Factual Comprehension in Listening)

\begin{tabular}{|cc|c|c|c|c|} 
& & Mean & $\mathrm{N}$ & Std. Deviation & Std. Error Mean \\
\hline Pair 1 & Factual (pre-test listening) & 3.30 & 20 & .865 & .193 \\
\hline & Factual (post-test listening) & 3.75 & 20 & .716 & .160 \\
\hline
\end{tabular}

Table 2. Paired Sample t-test (Factual Comprehension in Listening)

\begin{tabular}{|c|c|c|c|c|c|c|c|c|}
\hline & \multicolumn{5}{|c|}{ Paired Difference } & & & \multirow{3}{*}{$\begin{array}{l}\text { Sig. } \\
(2 \\
\text { tailed })\end{array}$} \\
\hline & \multirow[t]{2}{*}{ Mean } & \multirow[t]{2}{*}{$\begin{array}{l}\text { Std. } \\
\text { Deviation }\end{array}$} & \multirow[t]{2}{*}{$\begin{array}{l}\text { Std. } \\
\text { Error } \\
\text { Mean }\end{array}$} & \multicolumn{2}{|c|}{$\begin{array}{l}95 \% \text { Confidence } \\
\text { interval of the } \\
\text { difference }\end{array}$} & \multirow[t]{2}{*}{$\mathbf{t}$} & \multirow[t]{2}{*}{ df } & \\
\hline & & & & Lower & Upper & & & \\
\hline $\begin{array}{l}\text { Pair } 1 \\
\text { Listening } \\
\text { Pre-test } \\
\text { Factual } \\
\text { Post-test } \\
\text { Factual }\end{array}$ & -.450 & 1.050 & .235 & -.941 & .041 & -1.917 & 19 & .070 \\
\hline
\end{tabular}

Table 3. Paired Samples Statistics (Inferential comprehension in listening)

\begin{tabular}{|r|c|c|c|c|}
\hline & Mean & $\mathrm{N}$ & Std. Deviation & Std. Error Mean \\
\hline Pair 1 Inferential (Listening pre-test) & 1.00 & 20 & .324 & .073 \\
\hline Inferential (post-test listening) & 1.55 & 20 & .510 & .114 \\
\hline
\end{tabular}

The paired sample t-test (Table 2) of factual comprehension scores in listening tasks by the participants in the pre-test and post-test finds that the difference is not significant $(\mathrm{p}=.07, \mathrm{p}>.05)$. This implies that the difference between the two sets of scores is not significant.

RQ 2. Is there a significant difference in participants' performance in pre-test and post-test scores so far as their inferential comprehension in listening task is concerned? The comparison of the mean scores in inferential comprehension in listening tasks by the participants in the pre -test and post-test in Table $3(\mathrm{M}=1.00, \mathrm{SD}=.324$; $\mathrm{M}=1.55, \mathrm{SD}=.510$ ) shows a small increase.

The paired sample t-test (Table 4) of inferential comprehension scores in listening tasks by the participants in the pre-test and post-test finds that the difference is significant $(p=.000, p<.05)$. This implies that the difference between the two sets of scores is highly significant.

RQ 3. Is there a significant difference in participants' performance in pre-test and post-test scores so far as their response evaluation skill in listening task is concerned?

The comparison of the mean scores in questions seeking response evaluation in the listening tasks by the participants in the pre-test and post-test in Table 5 $(\mathrm{M}=.60, \mathrm{SD}=.754 ; \mathrm{M}=.90, \mathrm{SD}=.788)$ shows an increase.

The paired sample t-test (Table 6) of response evaluation scores in listening tasks by the participants in the pre-test and post-test finds that the difference is not significant $(p=.186, p>.05)$. This implies that the difference between the two sets of scores is not significant.

RQ 4. Is there a significant difference in participants' performance in pre-test and post-test scores so far as their paraphrase recognition skill in listening task is concerned?

The comparison of the mean scores in questions seeking response evaluation in the listening tasks by the participants in the pre-test and post-test in Table 7 $(\mathrm{M}=.75, \mathrm{SD}=.444 ; \mathrm{M}=.60, \mathrm{SD}=503$. $)$ shows a decrease. 
Table 4. Paired Sample test

\section{Paired Difference}

\begin{tabular}{|c|c|c|c|c|c|c|c|c|}
\hline & \multirow[t]{2}{*}{ Mean } & \multirow[t]{2}{*}{$\begin{array}{c}\text { Std. } \\
\text { Deviation }\end{array}$} & \multirow[t]{2}{*}{$\begin{array}{c}\text { Std. Error } \\
\text { Mean }\end{array}$} & \multicolumn{2}{|c|}{$\begin{array}{l}\text { 95\% Confidence } \\
\text { interval of the } \\
\text { difference }\end{array}$} & \multirow[t]{2}{*}{$t$} & \multirow[t]{2}{*}{ df } & \multirow{2}{*}{$\begin{array}{c}\text { Sig. } \\
\text { (2 tailed) }\end{array}$} \\
\hline & & & & Lower & Upper & & & \\
\hline Inferential & & & & & & & & \\
\hline $\begin{array}{l}\text { Listening Pre-test } \\
\text { Listening Post-test }\end{array}$ & -.550 & .510 & .114 & -.789 & -.311 & -4.819 & 19 & .000 \\
\hline
\end{tabular}

Table 5. Paired Samples Statistics (Response Evaluation)

\begin{tabular}{|cc|c|c|c|c|}
\hline & Mean & $\mathrm{N}$ & Std. Deviation & Std. Error Mean \\
\hline Pair 1 & $\begin{array}{c}\text { Response Evaluation } \\
\text { Listening (Pre-test) }\end{array}$ & .60 & 20 & .754 & .169 \\
\hline $\begin{array}{c}\text { Response Evaluation } \\
\text { Listening (Post-test) }\end{array}$ & .90 & 20 & .788 & .176 \\
\hline
\end{tabular}

The paired sample t-test (Table 8) of paraphrase recognition scores in listening tasks by the participants in the pre-test and post-test finds that the difference is not significant $(\mathrm{p}=.267, \mathrm{p}>.05)$. This implies that the difference between the two sets of scores is not significant.

Table 6. Paired Sample t-test (Response Evaluation)

\begin{tabular}{|c|c|c|c|c|c|c|c|c|}
\hline \multicolumn{9}{|c|}{ Paired Difference } \\
\hline & \multirow[t]{2}{*}{ Mean } & \multirow[t]{2}{*}{$\begin{array}{c}\text { Std. } \\
\text { Deviation }\end{array}$} & \multirow[t]{2}{*}{$\begin{array}{l}\text { Std. Error } \\
\text { Mean }\end{array}$} & \multicolumn{2}{|c|}{$\begin{array}{l}\text { 95\% Confidence } \\
\text { interval of the } \\
\text { difference }\end{array}$} & \multirow[t]{2}{*}{$\mathrm{t}$} & \multirow[t]{2}{*}{ df } & \multirow{2}{*}{$\begin{array}{l}\text { Sig. } \\
\text { (2 tailed) }\end{array}$} \\
\hline & & & & Lower & Upper & & & \\
\hline $\begin{array}{l}\text { Response Evaluation } \\
\text { (Pre-test) }\end{array}$ & -.300 & .979 & .219 & -.758 & .158 & -1.371 & 19 & .186 \\
\hline $\begin{array}{l}\text { Response Evaluation } \\
\text { (Post-test) }\end{array}$ & & & & & & & & \\
\hline
\end{tabular}

Table 7. Paired Samples Statistics (Paraphrase recognition in listening)

\begin{tabular}{|c|c|c|c|c|}
\hline & Mean & N & Std. Deviation & Std. Error Mean \\
\hline Pair 1 $\quad$ Paraphrase recognition & & & & \\
\hline $\begin{array}{c}\text { Listening (Pre -test) } \\
\text { Paraphrase recognition } \\
\text { Listening (Post-test) }\end{array}$ & .75 & 20 & .444 & .099 \\
\hline
\end{tabular}

RQ 5. Is there a significant difference in participants' performance in pre-test and post-test scores so far as their listening skills as a whole is concerned?

The comparison of the means of overall listening scores of the participants in the pre-test and post-test in Table
$9(\mathrm{M}=5.65, \mathrm{SD}=1.137 ; \mathrm{M}=6.80, \mathrm{SD}=1.361)$ shows an increase. The paired sample t-test (Table 10) of overall listening scores of the participants in the pre-test and post-test finds that the difference is significant $(p=.008$, $\mathrm{p}<.05)$. This implies that the difference between the two sets of scores is significant. 
Table 8. Paired Sample t-test (Paraphrase recognition in listening)

\section{Paired Difference}

\begin{tabular}{|l|l|l|c|c|c|c|c|c|}
\hline & Mean & $\begin{array}{c}\text { Std. } \\
\text { Deviation }\end{array}$ & $\begin{array}{c}\text { Std. Error } \\
\text { Mean }\end{array}$ & $\begin{array}{c}\text { 95\% Confidence } \\
\text { interval of the } \\
\text { difference }\end{array}$ & t & df & $\begin{array}{c}\text { Sig. } \\
\text { (2 tailed) }\end{array}$ \\
\cline { 4 - 7 } & & & Lower & Upper & & & \\
\hline $\begin{array}{l}\text { Paraphrase Recognition } \\
\text { (listening pre-test) }\end{array}$ & .150 & .587 & .131 & -.125 & .425 & 1.143 & 19 & .267 \\
\hline $\begin{array}{l}\text { Paraphrase Recognition } \\
\text { (listening post-test) }\end{array}$ & & & & & & & & \\
\hline
\end{tabular}

Table 9. Paired Samples Statistics (listening skills as a whole)

\begin{tabular}{|c|c|c|c|c|c|}
\hline & & Mean & $\mathrm{N}$ & Std. Deviation & Std. Error Mean \\
\hline \multirow[t]{2}{*}{ Pair 1} & Listening Pre-test & 5.65 & 20 & 1.137 & .254 \\
\hline & Listening Post-test & 6.80 & 20 & 1.361 & .304 \\
\hline
\end{tabular}

6.2 Qualitative analyses: The students enthusiastically took part in all the listening practice activities which were based on short 3 - 5 minutes BBC documentaries and popular English songs. The conversation on listening skills between the researcher and the participants in the WhatsApp group was very revealing. Many of the students agreed that learning languages from songs was an interesting idea. The effective and purposeful conversation also implied that chats could positively influence and support online language instructions. Having been able to drive home the idea that listening to good documentaries and songs could help develop listening skills, the researcher provided them with examples as to what good authentic English video texts are like.

Table 10. Paired Sample t-test (Listening scores as a whole)

Paired Difference

\begin{tabular}{|c|c|c|c|c|c|c|c|c|}
\hline & \multirow[t]{2}{*}{ Mean } & \multirow[t]{2}{*}{$\begin{array}{c}\text { Std. } \\
\text { Deviation }\end{array}$} & \multirow[t]{2}{*}{$\begin{array}{l}\text { Std. Error } \\
\text { Mean }\end{array}$} & \multicolumn{2}{|c|}{$\begin{array}{l}\text { 95\% Confidence } \\
\text { interval of the } \\
\text { difference }\end{array}$} & \multirow[t]{2}{*}{$t$} & \multirow[t]{2}{*}{$\mathrm{df}$} & \multirow{2}{*}{$\begin{array}{l}\text { Sig. } \\
\text { (2 tailed) }\end{array}$} \\
\hline & & & & Lower & Upper & & & \\
\hline $\begin{array}{l}\text { Listening Pre-test } \\
\text { Listening Post-test }\end{array}$ & -1.150 & 1.725 & .386 & -1.957 & -.343 & -2.981 & 19 & .008 \\
\hline
\end{tabular}

The researcher asked the students to subscribe to BBC Learning English Channel on the You Tube for more listening practice. Another interesting feature of the chats was the extensive use of emojis - the participants often used one emoji or another and the researcher also reciprocated with suitable ones. The scope for the exploitation of the emojis in group chats so as to create the right ambience for online engagements between the instructor/teacher and the students was a very significant discovery. It needs to be mentioned here that the enthusiasm during the performance of the tasks was infectious; during the practice session there would be a flood of screen shots of scores in the WhatsApp group. It can be said that the attempt at creating a virtual community of practice was quite successful.

\section{CONCLUSION}

The entire exercise was mainly aimed at rousing interest among the students for online listening which, it can be said with certain amount of confidence, that the researcher could achieve that goal. The students enthusiastically took part in the exercise which is evident from the interactions. The research endeavour also aimed at designing online listening tasks using authentic materials and available platforms. The experience in the project established the idea that WhatsApp and Google Form could be used for the development of online listening tests using authentic materials. The research also revealed that songs can be very effective authentic material for online listening practice. 
The quantitative data findings, however, brings up interesting results. While, the listening performance as a whole showed a significant development; the development was not significant so far as all the aspects of listening - factual comprehension, response evaluation and paraphrase recognition were concerned. The small number of students, questions and duration of the study might explain the mixed result. Nevertheless, the study throws revealing lights on the effective use of authentic materials (available in the web for free) for the development of listening skills in the local context with available apps and platforms such as WhatsApp and Google Form.

Future Directions: The current study has a few limitations - the short duration of the study and questions regarding the generalizability of the results because of the lack of a pure experimental design. Therefore,

a. a long-term case-study, \&t

b. an experimental research design on the effectiveness of using authentic listening materials available online could be right steps in the future direction.

\section{REFERENCES}

Hampels, R., Et Pleines, C. (2013). Fostering Student Interaction and Engagement in a Virtual Learning Environment: An Investigation into Activity Design and Implementation. CALICO Journal, 30(3), 342-370. Retrieved January 16, 2021, from http://www.jstor. org/stable/calicojournal.30.3.342

Kozar, 0. (2016). Text chat during video/audio conferencing lessons: Scaffolding or getting in the way? CALICO Journal, 33(2), 231-259. doi:10.2307/ calicojournal.33.2.231

LAI, C., ZHA0, Y., \& WANG, J. (2011). Task-Based Language Teaching in Online Ab Initio Foreign
Language Classrooms. The Modern Language Journal, 95, 81-103. Retrieved January 17, 2021, from http:// www.jstor.org/stable/41413421

Macaro, E., Graham, S., \&t Vanderplank, R. (2007). A review of listening strategies: focus on sources of knowledge and on success. In A. D. Cohen, \& E. Macaro (Eds.), Language Learner Strategies: Thirty Years of Research and Practice (pp. 165-206). Oxford: Oxford University and Press.

Ozverir, I., Osam, U., \& Herrington, J. (2017). Investigating the Effects of Authentic Activities on Foreign Language Learning: A Design-based Research Approach. Journal of Educational Technology \& Society, 20(4), 261-274. Retrieved January 17, 2021, from http:// www.jstor.org/stable/26229222

Rosell-Aguilar, F. (2017). State of the App: A Taxonomy and Framework for Evaluating Language Learning Mobile Applications. CALICO Journal, 34(2), 243-258. doi:10.2307/90014690

SATO, E., CHEN, J., \& JOURDAIN, S. (2017). Integrating Digital Technology in an Intensive, Fully Online College Course for Japanese Beginning Learners: A StandardsBased, Performance-Driven Approach. The Modern Language Journal, 101(4), 756-775. Retrieved January 16, 2021, from http://www.jstor.org/stable/44981031

Ur, P. (1996). A Course in Language Teaching: Practice and Theory (First South Asian Edition 2005 ed.). Cambridge: Cambridge University Press.

Yu-Lin Jeng, Ting-Ting Wu, Yueh-Min Huang, Qing Tan, \&t Stephen J. H. Yang. (2010). The Add-on Impact of Mobile Applications in Learning Strategies: A Review Study. Journal of Educational Technology \& Society, 13(3), 3-11. Retrieved August 1, 2020, from www.jstor. org/stable/jeductechsoci.13.3.3 